\title{
PENINGKATAN PRODUKTIVITAS SAPI RAKYAT, PEMBUATAN YOGURT, PERMEN SUSU DAN MENINGKATKAN KESEHATAN MASYARAKAT DI KECAMATAN PACET KABUPATEN MOJOKERTO
}

\section{INCREASING PRODUCTIVITY OF PEOPLE'S CATTLE, MAKING YOGHURT, MILK CANDIES AND IMPROVING PUBLIC HEALTH IN PACET, MOJOKERTO}

\author{
Widjiati \\ Departemen Anatomi Veteriner Fakultas Kedokateran Hewan Universitas Airlangga \\ Kampus C, Jl. Mulyorejo Surabaya 60115 Phone. (031)5992785 Fax. (031)5991530 Email : widjiati1962@gmail.com
}

\author{
Trilas Sardjito
}

Departemen Reproduksi Veteriner Fakultas Kedokateran Hewan Universitas Airlangga

Kampus C, Jl. Mulyorejo Surabaya 60115 Phone. (031)5992785 Fax. (031)5991530

\author{
Nenny Harijani \\ Departemen Kesehatan Masyarakat Veteriner Fakultas Kedokateran Hewan Universitas Airlangga \\ Kampus C, Jl. Mulyorejo Surabaya 60115 Phone. (031)5992785 Fax. (031)5991530
}

\begin{abstract}
Abstrak
Kabupaten Mojokerto merupakan daerah dengan tingkat ekonomi yang baik. Kabupaten ini memiliki lahan subur dan Kerajaan Majapahit yang terpelihara dengan baik. Selain itu, ia memiliki peternakan sapi perah yang terletak di sekitar Kecamatan Pacet. Susu yang dihasilkan dari daerah ini bisa menunjang perekonomian di Jawa Timur. Namun, tidak ada kenaikan harga jual susu olahan susu menjadi makanan dengan harga jual tinggi. Komunitas sapi perah belum tersentuh oleh teknologi pengolahan susu untuk menghasilkan makanan dengan harga jual tinggi seperti yoghurt, es krim, atau permen susu. Oleh karena itu, sains dan teknologi sangat dibutuhkan oleh masyarakat di daerah ini untuk meningkatkan produktivitas dan pendapatannya agar tercipta perekonomian mandiri. Pelayanan sosial ini bertujuan untuk membantu masyarakat dalam rangka meningkatkan pendapatan mereka dengan menguasai sains dan teknologi dalam bentuk kenaikan harga jual susu dan menciptakan ekonomi mandiri dengan meningkatkan produktivitas sapi perah dan memberi nilai tambah susu untuk diolah makanannya. seperti permen susu atau yoghurt. Pelayanan sosial terintegrasi, untuk memberi sains dan teknologi kepada masyarakat, untuk memotivasi siswa dan masyarakat agar tetap menjaga kesehatan dan merawat giginya. Sasaran kegiatan ini adalah mengurangi beban masyarakat dengan meningkatkan pengelolaan produktivitas sapi dan produktivitas sapi perah, membuat produk olahan dari susu dengan nilai ekonomi lebih tinggi, menciptakan industri skala kecil, dan meningkatkan kesehatan masyarakat. Kegiatan yang dilakukan adalah sebagai berikut memberikan pelatihan untuk membuat yoghurt, permen susu atau herbal, memberikan layanan kesehatan sapi untuk meningkatkan produktivitas ternak dengan menjalani pemeriksaan kesuburan ternak, mengobati ternak yang tidak subur, melakukan inseminasi buatan pada ternak dalam siklus estrus mereka, memberi vitamin untuk meningkatkan ternak. nafsu makan, meningkatkan kualitas pakan ternak dengan memberikan pelatihan untuk mengolah pakan ternak. Briefing dan pelayanan kesehatan diberikan untuk mendidik masyarakat agar dapat hidup sehat dengan menjaga kesehatan dan merawat gigi. Kesimpulan yang diambil dari kegiatan yang dilakukan di Kecamatan Pacet Mojokerto adalah pelatihan bagaimana membuat yoghurt dan permen susu mampu memberi nilai tambah bagi masyarakat di Kecamatan Pacet. Banyak kasus gangguan reproduksi ternak di Kecamatan Pacet diidentifikasi, dan pengukuran pertumbuhan anak sekolah dasar diperlukan untuk memantau status gizi anak-anak.
\end{abstract}

Kata kunci: Pacet, permen susu, sapi perah, yoghurt

\footnotetext{
Abstract

Mojokerto Regency is a region with a good economic level. The regency has fertile land and well-preserved Majapahit Kingdom remains. In addition, it has dairy cattle farm located around Pacet Sub-district. Milk produced from this area can support economy in East Java. However, there is no increased milk sale price of dairy processing to be food with high sale price. Dairy cattle community have not been touched by technology
} 
of dairy processing to produce high sale priced food such as yoghurt, ice-cream, or dairy candies. Therefore, science and technology are needed by the community in this area to increase their productivity and income in order to create independent economy. The social service is aimed to assist the community in order to increase their income by mastering science and technology in the form of increasing the sale price of milk and creating independent economy by increasing dairy cattle productivity and giving added value of milk to be processed food such as dairy candies or yoghurt. The social service is integrated, in order to give science and technology to the community, to motivate the students and community to keep their health and to take care of their teeth. The target of the activity is to lessen the community's burden by improving management of cattle caring and dairy cattle productivity, making processed products from milk with higher economic value, creating small scaled industry, and improving public health. The activities conducted were as follows giving trainings to make yoghurt, dairy candies or herbs, giving cattle health service to increase cattle productivity by undergoing cattle fertility examination, treating infertile cattle, doing artificial insemination to cattle in their estrous cycle, giving vitamin to increase cattle appetite, improving cattle feed quality by giving trainings to process cattle feed. Briefing and service on health was given to educate the community in order to live healthily by keeping health and taking care of teeth.The conclusion drawn from the activity conducted in Pacet Sub-district Mojokerto is training on how to make yoghurt and dairy candies is able to give added value for the community in Pacet Sub-district. Many cases on cattle reproductive disorder in Pacet Sub-district are identified, and measurement on Elementary school children's growth is needed to monitor nutritional status of the children.

Keywords: dairy cattle, dairy candies, Pacet, yogurt

\section{PENDAHULUAN}

Bila dilihat dari segi geografis, mata pencarian penduduk, populasi ternak dan daya dukung alam berupa pertanian maka daerah Kabupaten Mojokerto berpotensi baik untuk pengembangan ternak pada umumnya dan ternak sapi perah pada khususnya. Kabupaten Mojokerto merupakan daerah dengan tingkat perekonomian yang cukup maju. Wilayah kabupaten Mojokerto sangat subur dengan situs-situs peninggalan jaman kerajaan Majapahit yang masih terjaga dengan baik. Wilayah sekitar kecamatan Pacet merupakan daerah sentra pemeliharaan sapi perah. Produksi susu dari daerah ini mampu menompang sentra perekonomian di Jawa Timur.

Saat ini pengembangan sapi perah sebagai salah satu komoditas unggulan sub sektor peternakan yang perlu mendapat perhatian serius, mengingat permintaan akan protein hewani baik daging, telur dan susu belum semuanya dapat dipenuhi oleh produksi dalam negeri. Untuk memenuhi kekurangan tersebut secara nasional, pemerintah mengimpor daging, susu maupun sapi dari luar negeri.

Daya dukung lahan untuk menghasilkan hijau pakan ternak berpengaruh terhadap pola pemberian pakan ternak. Pada musim kemarau yang panjang pakan ternak hanya berasal dari jerami kering tanpa pengolahan, sedangkan pada musim penghujan hijauan pakan ternak berlimpah. Kondisi ini akan mempengaruhi kondisi kesehatan ternak sapi perah dan dalam jangka waktu lama akan menurunkan produktivitas dan reproduktivitas ternak sapi perah.

Kurangnya ketersediaan pakan ternak yang berkualitas baik akan berpengaruh terhadap usaha pemenuhan kebutuhan protein hewani masyarakat, hal tersebut dapat ditingkatkan apabila kualitas dan kuantitas ternak dapat terpenuhi dengan baik. Salah satu usaha yang dapat dilakukan untuk peningkatan produktifitas dan jumlah ternak adalah dengan memperhatikan tingkat konsumsi pakan yang berkualitas baik. Upaya untuk mengatasi tersebut diatas dipandang perlu untuk menambah pengetahuan petani peternak melalui pembinaan dan penyuluhan tentang cara pengolahan jerami padi melalui teknologi pemanfaatan probiotik agar dapat memenuhi kebutuhan pokok ternak ruminansia akan protein dan dapat diberikan sepanjang tahun terutama pada musim kemarau.

Pada ternak ruminansia seperti sapi, kerbau, kambing dan domba membutuhkan hijauan sebagai makanan pokok yang dapat terpenuhi pada musim penghujan, tetapi pada musim kemarau kebutuhan tersebut sulit terpenuhi. Salah satu upaya untuk mengatasi kekurangan hijauan terutama dimusim kemarau digunakan pakan alternative yang merupakan limbah pertanian yang murah dan mudah didapat yaitu jerami padi yang ketersediaannya melimpah terutama pada musim panen (Wahyuni, dkk 2005). Demikian pula dalam menjaga agar dapat diberikan pakan yang baik sepanjang tahun, maka perlu dilakukan pengawetan hijauan melalui teknologi pemanfaatan probiotik Salah satu bahan yang dapat dipakai sebagai bahan dasar adalah dengan menggunakan bahan dari jerami padi. Pemanfaatan dan pengawetan jerami padi dengan fermentasi menggunakan mikroorganisme yang merupakan pemrosesan secara biologis relative murah dan keamanan terjamin, maka kami tim Pengabdian Kepada Masyarakat berkeinginan mengadakan pengenalan pengawetan limbah jerami pada melalui proses fermentasi yang dapat meningkatkan konsumsi pakan ternak sehingga dapat meningkatkan produktifitas serta jumlah ternak di wilayah Kecamatan Pacet.

Kurangnya ketersediaan pakan ternak yang berkualitas baik akan berpengaruh terhadap usaha pemenuhan kebutuhan protein hewani masyarakat, hal tersebut dapat ditingkatkan 
apabila kualitas dan kuantitas ternak dapat terpenuhi dengan baik. Salah satu usaha yang dapat dilakukan untuk peningkatan produktifitas dan jumlah ternak adalah dengan memperhatikan tingkat konsumsi pakan yang berkualitas baik. Keuntungan yang dapat diperoleh dari penyimpanan hijauan dengan metode ini dapat memperpanjang waktu penyimpanan hijauan, sehingga dapat mengurangi pengaruh cuaca terhadap kesediaan pakan.

Penggunaan jerami padi sebagai pakan ternak alternative pengganti hijauan pada musim kemarau, karena jumlahnya banyak pada musim panen, mudah didapat dan tidak bersaing dengan manusia, serta dapat memenuhi kebutuhan ternak akan hijauan sepanjang tahun (Soejono 1999). Jerami padi termasuk tanaman yang tua karena diperoleh dari tanaman padi yang telah tua dan siap dipanen, pada tanaman tua akan mengalami perubahan komposisi terutama pada bahan kering, yaitu protein kasarnya semakin menurun, kadar air pada awal pertumbuhan tinggi akan turun seiring dengan pertumbuhan tanaman. Demikian pula selulosa, hemiselulosa dan lignin akan mengalami peningkatan sejalan dengan peningkatan umur tanaman, selain itu jerami padi juga mengandung lignin dan kristal silikat yang sangat sulit dicerna oleh ternak dan merupakan penyebab rendahnya daya cerna (McDonald et al. 1994; Kusriningrum dkk 2001).

Pemanfaatan jerami padi dengan fermentasi menggunakan mikroorganisme asam laktat sangat efisien dalam mendegradasi pati, kitin dan polisakarida pada dinding sel tanaman karena bakteri asam laktat dapat menghasilkan enzim eksoselulitik dan endoselulitik yang dapat mendegradasi komponen serat kasar, sehingga mengurangi kehilangan bahan kering dan meningkatkan nutrisi khususnya kadar gula yang terlarut serta dapat meningkatkan kandungan protein kasar dan menurunkan kandungan serat kasar (Nurhajati dkk, 1996; Wahjuni. dkk, 2005).

Target yang hendak dicapai dari kegiatan pengabdian masyarakat ini adalah perbaikan manajemen pemeliharaan ternak sapi perah, meningkatkan produktivitas sapi perah, menghasilkan produk olahan dari susu sapi, memperbaiki kualitas pakan ternak yang ada dengan memanfaatkan teknologi fermentasi menggunakan probiotik agar bernilai gizi tinggi, meningkatkan kesehatan masyarakat dan melakukan pengukuran tumbuh kembang anak dengan metode antrophometri

\section{METODE PELAKSANAAN}

Metode yang digunakan dalam pelaksanaan kegiatan pengabdian kepada masyarakat ini dilakukan dalam tiga tahap kegiatan meliputi:

Tahap Pembinaan: Penyuluhan pengolahan limbah jerami padi melalui teknologi fermentasi menggunakan probiotik sebagai solusi kelangkaan pakan dimusim kemarau.
Adapun materi pembinaan yang disampaikan meliputi: Manfaat dan keuntungan penyimpanan hijauan dengan teknologi fermentasi menggunakan probiotik, Bahan yang diperlukan dan Prosedur pembuatan. penyuluhan tentang penanganan pasca panen produk peternakan sapi perah. Meliputi pemeliharaan Kesehatan Sapi, Lingkungan yang Bersih, Teknik Pemerahan Susu, Penyimpanan Susu, Pengujian Susu, Pencucian dan sanitasi sarana dan peralatan. Penyuluhan untuk menjaga kesehatan masyarakat dan pemantauan tumbuh kembang anak dengan metode antrophometri.

Tahap Pelatihan. Dalam upaya untuk meningkatkan ketrampilan dan pengetahuan peternak dan masyarakat kecamatan Pacet mengenai reproduksi, pakan dan penanganan pasca panen, maka akan dilakukan demo serta pelatihan cara pembuatan dan cara penggunaan teknologi fermentasi menggunakan probiotik agar nantinya dapat menerapkan teknologi ini secara baik dan benar. Pengolahan susu menjadi Yogurt dan permen susu.

Tahap Evaluasi. Mencatat hasil produksi sapi perah dari beberapa parameter yang diamati antara lain adalah Calving interval, Gestation Period, Konsumsi pakan, Nilai Konversi Pakan (Feed Convertion Rate $=\mathrm{FCR}$ ). Memantau pengembangan dari ketrampilan yang telah diberikan

\section{HASIL DAN PEMBAHASAN}

Pelaksaan pengabdian Masyarakat program Iptek Bagi Masyarakat (IbM) telah dilaksanakan Di Kecamatan Pacet Kabupaten Mojokerto yang seluruh kegiatan terbagi pada beberapa desa. Pembukaan Kegiatan Pengabdian masyarakat ini dilaksanakan pada tanggal 9 Mei 2015 di pendopo kecamatan Pacet, yang dihadiri oleh tim pengabdian masyarakat Universitas Airlangga, jajaran Satuan Kerja pemerintahan Daerah (SKPD)kecamatan Pacet dan masayarakat Kecamatan Pacet. Kegiatan ini meliputi pengobatan dan pelatihan.

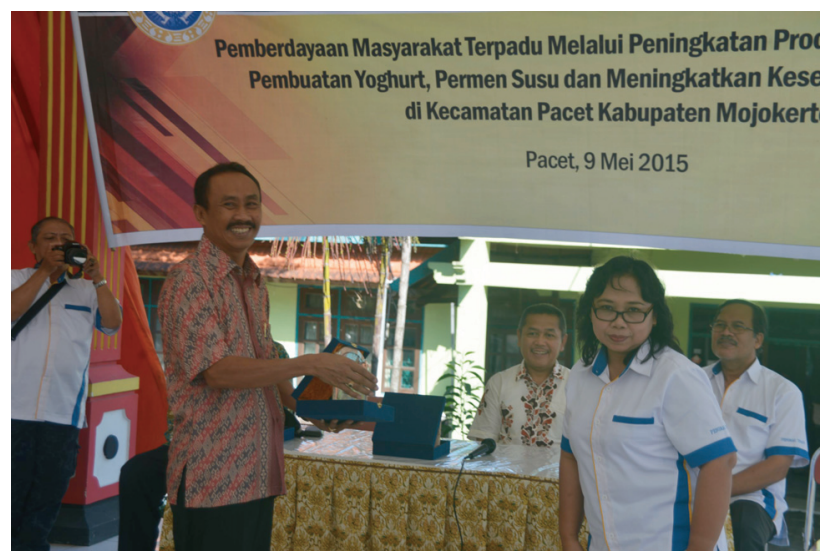

Gambar 1. Pembukaan Pengabdian Masyarakat Program Iptek Bagi Masyarakat Di Kecamatan Pacet 
Pemeriksaan dan pengobatan gangguan reproduksi pada sapi perah dilaksanakan di desa Cempoko Limo dan Desa Claket dengan memeriksa sapi perah yang mengalami gangguan reproduksi. Total jumlah sapi yang telah diperiksaan adalah sebanyak 200 ekor, dan yang mengalami gangguan reproduksi cukup tinggi. Hal ini mengingat sapi perah dengan kondisi tiap hari diperah dan penangan manajemen ternak kurang baik, maka sering menimbulkan terjadinya gangguan reproduksi sehingga sapi menjadi infertil dan produksi susunya menurun karena jangka waktu kembali beranak sangat panjang.

Program pengabdian masyarakat ini adalah untuk memberikan pemahaman pada para peternak untuk bisa mendeteksi lebih dini gejala terjadinya gangguan reproduksi pada ternaknya sehingga tidak terlambat melakukan pengobatan dan dapat mencegah penurunan produksi susu.

Pelaksaan kegiatan ini dilakukan dari kandang ke kandang mengingat lokasi/medan kegiatan yang tidak datar tanahnya sehingga resiko jika mengumpulkan peternak dan sapinya dalam satu lapangan terbuka. Untuk jelasnya data jumlah sapi yang mengalami gangguan reproduksi dapat dilihat pada tabel dibawah ini.

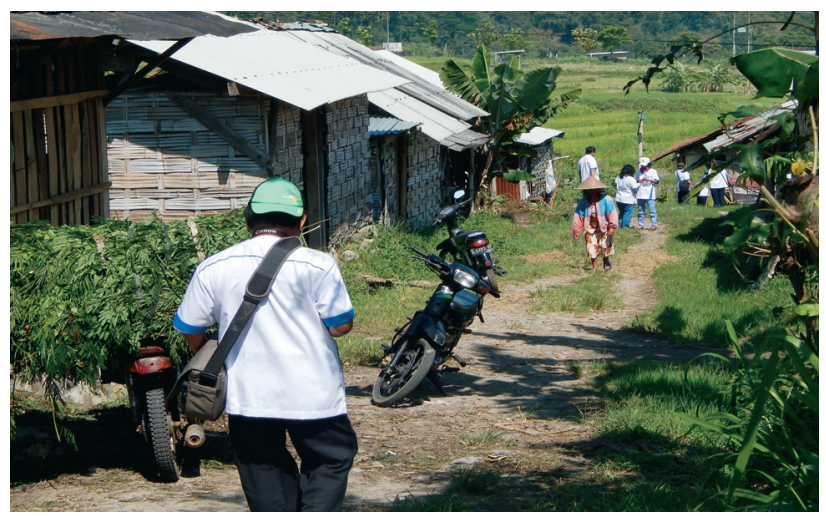

Gambar 2. Lokasi Pemeriksaan Gangguan Reproduksi

Kegiatan pelatihan pembuatan yogurt dan permen susu dilaksanakan di pendopo Kecamatan Pacet, yang diikuti oleh 50 orang yang terdiri dari ibu-ibu PKK dan pemilik ternak sapi perah. Kegiatan ini terlasana bekerjasama dengan tim penggerak PKK Kecamatan Pacet dan Satuan Kerja kantor perindustrian Kecamatan Pacet. Mengingat Pacet adalah daerah sapi perah, yang menghasilkan susu sapi dan Pacet juga merupakan daerah wisata, maka pelatihan pembuatan yogurt dan permen susu akan membantu masyarakat meningkatkan nilai jual susu sapi dan meningkatkan pendapatan masyarakat. Pacet daerah wisata yang pada hari libur sangat banyak dikunjungi turis dari luar kota pacet. Pengolahan susu menjadi yogurt dan permen susu akan memberikan nilai tambah kepada masyarakat, dan akan membuka peluang pasar mengingat Pacet daerah wisata. Kegiatan program pelatihan pembuatan yogurt dan permen susu dapat dilihat pada gambar dibawah ini.

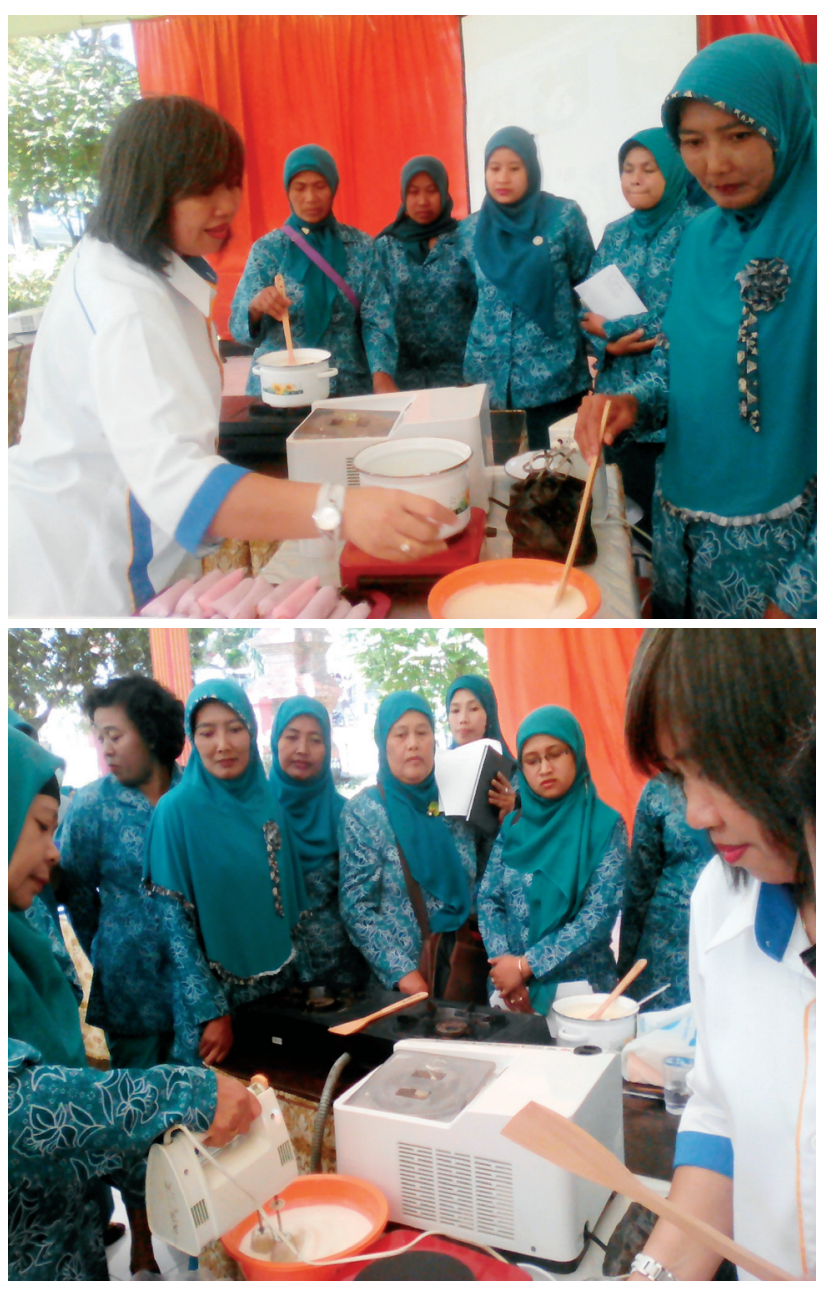

Gambar 3. Pelatihan Pembuatan Yogurt dan Permen Susu

Kegiatan Iptek bagi Masyarakat ini juga melakukan pemeriksaan kesehatan masayarakat dan pengukuran tumbuh

Tabel 1. Data Pemeriksaan dan Pengobatan Hewan Yang Mengalami Gannguan Reproduksi

\begin{tabular}{lccl}
\hline $\begin{array}{c}\text { Lokasi } \\
\text { Kegiatan }\end{array}$ & $\begin{array}{c}\text { Jumlah Ternak } \\
\text { Yang Diperiksa }\end{array}$ & $\begin{array}{c}\text { Jumlah Sapi mengalami } \\
\text { ganguan Reproduksi dan } \\
\text { mendapatkan pengobatan }\end{array}$ & \multicolumn{1}{c}{ Jenis Gangguan Reproduksi } \\
$\begin{array}{l}\text { Desa Cempoko } \\
\text { Limo }\end{array}$ & 100 ekor & 45 ekor & $\begin{array}{l}\text { Corpus Luteum Persisten, hipofungsi, Kista folikel, } \\
\text { Atropi, Nymphomani }\end{array}$ \\
\hline Desa Claket & 100 ekor & 35 ekor & $\begin{array}{l}\text { Corpus Luteum Persisten, hipofungsi, Kista folikel, } \\
\text { Atropi, Nymphomani }\end{array}$ \\
\hline
\end{tabular}


kembang anak Sekolah Dasar untuk memantau status gisi anak-anak sekolah dasar. Pengobatan pada masayarakat diikuti oleh 200 orang masayarakat Kecamatan Pacet yang terdiri laki dan perempuan. Pengukuran tumbuh kembang anak SD dilakuakn pada 200 anak SD Pacet I dan SD Pacet 2. Gambar kegiatan tersebut dapat dilihat pada gambar dibawah ini.

\section{Antropometri}

Kegiatan pengabdian Ipteks bagi Masyarakat ini, kami melibatkan tenaga bantuan dari kolega Fakultas Kedokteran Universitas Airlangga untuk melakukan pemeriksaan dan pengobatan kepada masyarakat Kecamatan Pacet dan Kolega dari Departemen Anthropologi Fakultas Ilmu Sosial Dan Politik Universitas Airlangga untuk pemeriksaan tumbuh kembang anak anak SDN Pacet I dan II. Demikian juga saat melakukan pemeriksaan dan pengobatan gangguan
Reproduksi maupun pelatihan pembuatan yogurt dan permen susu kami melibatkan sejawat dari departemen reproduksi dan Kesehatan Masyarakat Veteriner Fakultas Kedokteran Hewan Universitas Airlangga.

Kami melakukan monitoring keberlanjutan hasil dari pelatihan yogurt dan permen susu yang telah diberikan. Tim Berharap teknologi yang sudah diberikan bisa diterapkan sehingga bisa menambah penghasilan masyarakat dan meningkatkan nilai jual susu sapi. Sebagai tindak lanjut kegiatan pengabdian Ipteks bagi Masyarakat ini kami juga melakukan pelatihan pemeriksaan tumbuh kembang anak SD dengan metode antrophometri pada beberapa kader PKK dan memberikan seperangkat peralatan pengkuran antrophometri. Selama ini kader PKK hanya memantau tumbuh kembang anak BALITA melalui penimbangan berat badan bayi, sedangkan tumbuh kembang anak SD terutama kelas 1-3 belum pernah dilakukan.

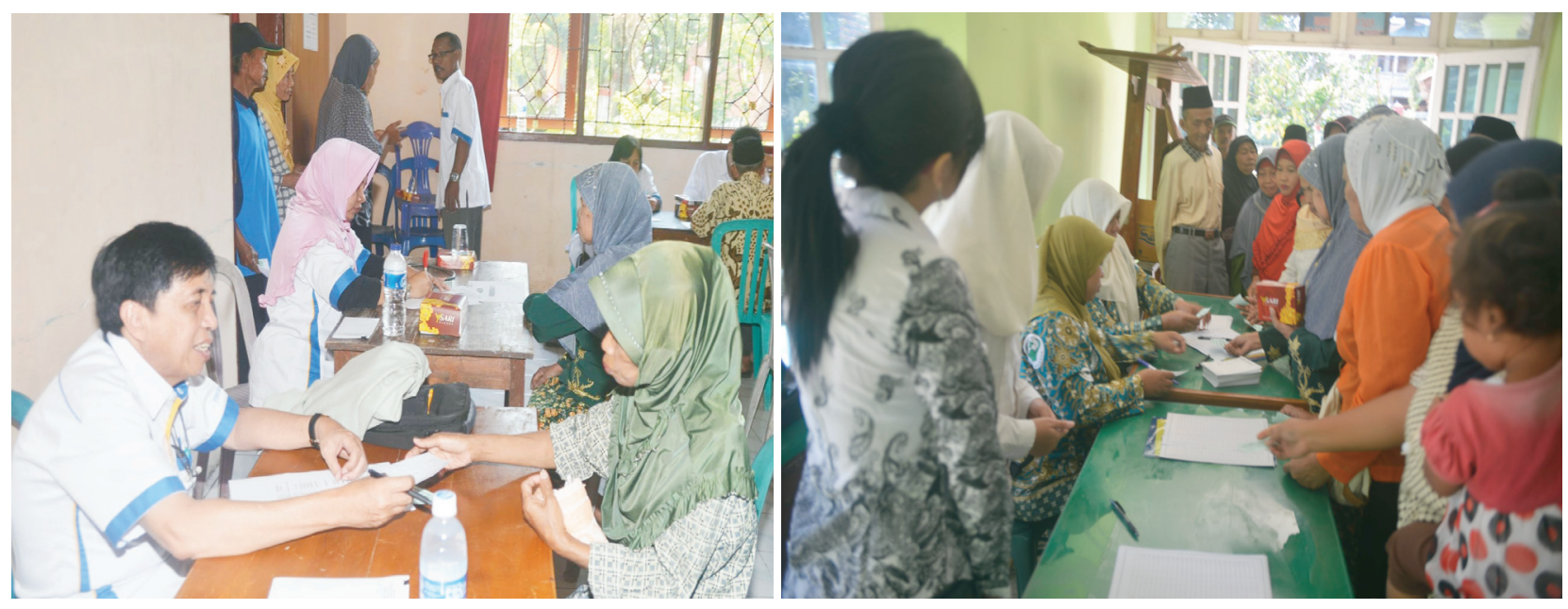

Gambar 4. Pelaksanaan Pemeriksaan Kesehatan Masyarakat Kecamatan Pacet
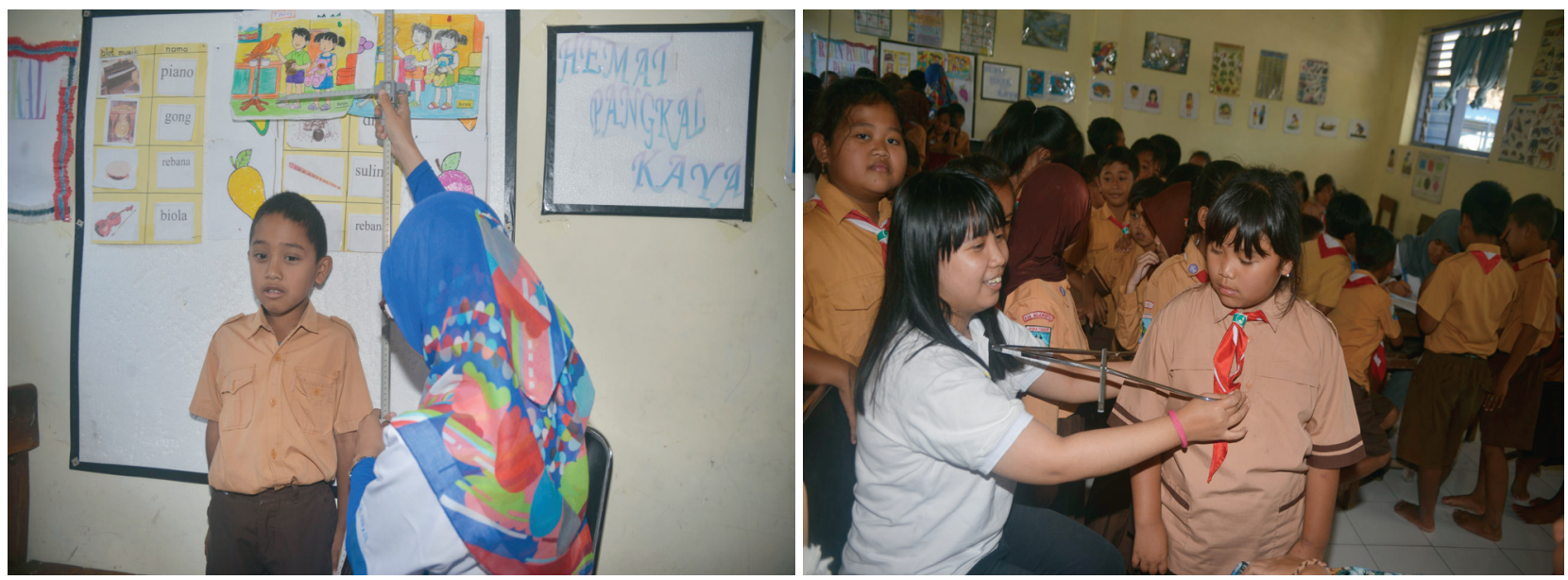

Gambar 5. Pemeriksaan Tumbuh Kembang Anak Sekolah Dasar dengan metode 


\section{SIMPULAN}

Kesimpulan dari kegiatan Ipteks bagi Masyarakat yang telah dilaksanakan di Kecamatan Pacet Kabupaten Mojokerto adalah sebagai berikut Ada 3 orang masyarakat kecamatan Pacet yang sudah melakukan pembuatan yogurt dan permen susu. Masih Banyak ditemukan kasus gangguan reproduksi pada peternakan sapi perah masyarakat di Kecamatan Pacet. Sudah dilakukan pengukuran tumbuh kembang anak SD dan masih diperlukan untuk memantau status gizi anak

\section{DAFTAR PUSTAKA}

Hafez, 1993. Reproduction in Farm Animals. 6 th Edition . Philadelphia: Lea and Febiger.

Hardjopranjoto, 1995. Ilmu Kemajiran Pada Terrnak. Surabaya: Airlangga United Press .

Kusriningrum, R., H. Setyono., T.nurhajati., Agustono., M.Arief., A.alarif, M.Lamid. 2001. Pengetahuan Bahan Pakan Ternak. Laboratorium Ilmu Makanan Ternak. Surabaya: FKH-Unair

Mc Donald, P., R.A. Edward and J.F.G. Greenhalg. 1994. Animal Nutrition $4^{\text {th }}$ Edition. London and New York: Longman.

Mulyono, S dan Sarwono,B. 2004. Beternak Domba Prolifik. Yogyakarta: Penebar Swadaya.
Nurhajati, T., R.S.Wahjuni dan De Vries, G.C. 1996. Analisis Ekonomi Penggunaan Ampas Tahu terfermentasi dengan subsitusi Pakan terhadap Performa,Daya Cerna Pakan, Kualitas Daging Serta Gambaran darah Ayam Pedaging Jantan.Surabaya : Lembaga Penelitian Universitas Airlangga.

Partodiharjo, 1992. Ilmu Reproduksi Ternak. Jakarta: Mutiara Sumber Widya.

Toelihere, 1984. Ilmu Kemajiran Pada Ternak. Bogor: IPB Press.

Romziah, B., Wahjuni., R.S., Bijanti, R. 2002. Kajian Kualitas dan Potensi Formula Pakan Komplit "VETUNAIR " Terhadap Pertumbuhan Pedet, Produksi dan Kualitas Air Susu Sapi Perah. Surabaya: Hibah Penelitian Due-Like. Fakultas Kedokteran Hewan Universitas Airlangga.

Soejono, M. 1995. Perubahan struktur dan kecernaan Jerami Padi akibat Perlakuan Urea Sebagai Pakan Sapi Potong. Disertasi S-3 Universitas Gadjah Mada. Yogyakarta.

Wahjuni,R.S., Bijanti, R., Romziah, B.S. 2005. Profil Metabolit Domba yang Diberi Suspensi Bakteri Asam Laktat dan Yeast Pada Rumput Gadjah Dan Jerami Padi. Surabaya: Hibah Penelitian Due-Like. Fakultas Kedokteran Hewan Universitas Airlangga. 